\title{
THE JOURNEY OF CRISPR-CAS9 FROM BACTERIAL DEFENSE MECHANISM TO A GENE EDITING TOOL IN BOTH ANIMALS AND PLANTS
}

\author{
TAHIR T, *ALI Q, RASHID MS, MALIK A
}

\author{
Institute of Molecular Biology and Biotechnology, The University of Lahore, Lahore, Pakistan \\ Corresponding author emails: saim1692@gmail.com
}

\begin{abstract}
Today we can use multiple of endonucleases for genome editing which has become very important and used in number of applications. We use sequence specific molecular scissors out of which, most important are mega nucleases, zinc finger nucleases, TALENS (Transcription Activator Like-Effector Nucleases) and CRISPR-Cas 9 which is currently the most famous due to a number of reasons, they are cheap, easy to build, very specific in nature and their success rate in plants and animals is also high. Who knew that one day these CRISPR discovered as a part of immune system of bacteria will be this much worthwhile in the field of genetic engineering? This review interprets the science behind their mechanism and how several advancements were made with the passage of time to make them more efficient for the assigned job.
\end{abstract}

Keywords: CRISPR-Cas9, endonucleases, gene editing, immune system, zinc finger, TALENS

\section{Introduction}

It is foreseen that the world's human population will increase to 10 billion by 2050 and with the increasing population the global requirement of food will grow to $25 \%$ to $70 \%$ of the current production rate (Hunter et al., 2017). In order to feed the world it is important to fight against pathogens which are resulting in yield loss of 20-40\% around the globe (Savary et al., 2012). To overcome the challenges including increase in yield, pathogen resistance, crop improvement it was important to develop some techniques that could replace the conventional selective breeding and induce changes in the genetic makeup of crops. Up till 1970s it was not possible to achieve successful genetically modified organisms. The first transgenic organism that came into existence was by inserting an exogenous DNA into the plasmid of $E$. coli without interrupting any of bacteria's own biological function (Cohen et al., 1973). However this was risky process as there were possibilities that the exogenous DNA may interfere with the bacterial DNA and mutate it. There were also the chances of mismatches. Then a technique came, in which the DNA sequence to be delivered were homologous to the sequence that was targeted in the other organism thus giving more specificity and less chances of mismatches. This particular technique was the footstep of gene editing technology (Szostak et al., 1983). Its widespread use was limited due to its inefficiency but it was used widely for research purposes. Under the following decades after collecting so much knowledge and after so many studies came the genome editing through programmable endonucleases, which is the most advanced and recent technique. These endonucleases for plants include zinc finger nucleases, transcription effector like nucleases, and CRISPR-Cas9 (Shah et al., 2018; Bao et al., 2019). CRISPR is a ground breaking tool due to its potential to treat human diseases and edit human genome. It has helped to identify and understand the procedure of diseases (Zhou et al., 2014), It has helped generate animal disease models (Xue et al., 2014). It has assisted in advancing genetic engineering in crops (Zhang et al. 2017). The objective of this mini review is to highlight the features of CRISPR, its advantages and drawbacks over other techniques and to know the reason behind all the fame and publicity and also some of the work done on specific crops.

\section{History and origin of CRISPR}

Recently, CRISPR-Cas9 are stealing the show due to their number of attributes. Ishino was the scientist who was analyzing the gene that would conduct isozyme conversion of alkaline phosphatase about 30 years ago and while performing his experiment, he had no idea that he would discover the first ever CRISPRs from Escherichia coli (Ishino et al., 1987). By that time it was very mysterious and unexpected, scientist couldn't find out the function of these repeated sequences because the human genome project did not begin its function of sequencing the genome of organisms that have therapeutic importance at that time. Then after being detected in bacteria they were for the first time seen in archaea in

[Citation: Tahir, T., Ali, Q., Rashid, M.S., Malik, A. (2020). The journey of CRISPR-cas9 from bacterial defense mechanism to a gene editing tool in both animals and plants. Biol. Clin. Sci. Res. J., 2020: 17. doi: https://doi.org/10.54112/bcsrj.v2020i1.17] 
1993, more precisely in Haloferax mediterranei and the man behind the discovery was Mojica who also found out after some years that the function of these sequences found in bacteria and archaea is similar (Mojica et al., 1993;2000) Janses named them CRISPR in 2002 (Janses et al., 2002) Then four years later Eugene conveyed that the CRISPR-Cas9 system was a prokaryotic RNA interference-based immune system (Makarova et al., 2006). In 2007 it was proven practically that they are truly part of the adaptive defensive mechanism of prokaryotes while using the lactic acid bacterium Streptococcus thermophiles (Barrangou et al., 2007). In short in 2012 the face of CRISPR was unveiled and by this time scientist knew how they could use this system for cutting the target DNA outside the cell (Gasiunas et al., 2012). Then the very next year this system taken from streptococcus pyogenes was applied to genome edit human nerve and the kidney cells of mouse (Cong, Mali et al., 2013). Beginning an era of targeted genome editing which is easier in handling.

\section{Structure of CRISPR loci}

Clustered regularly interspaced short palindromic repeats are found in bacteria and archea as the part of their immune system, they were first analyzed in Streptococcus pyogenes and classified as type 2 (Langner et al., 2018). Streptococcus pyognenes is known to cause lethal infections in humans from less severe sore throat to a range of infections. It belongs to the gram positive type of bacteria and works by making colonies in the pharynx (part of throat) and skin (Rosinski-Chupin et al., 2019). These are a family of DNA sequences consisting of 2 important components, Cas 9 endonuclease and single guide RNA (gRNA) which further consist of pre-crRNA and the trans-activating crRNA also known as tracrRNA (Weeks et al., 2016). Cas 9 endonuclease is a protein and as the name indicates it is an enzyme involved in cleavage, the customizable guide RNA is to escort the enzyme to the site of target sequence (Jiang and Doudna, 2017; Khatodia et al., 2016). As the name clearly shows CRISPR consist of short repeats that are 28-37 bp sequences in length (Barrangou et al., 2014), these sequences are unique from each other but are of similar length and are separated from each other from spacers. Every repeat is arranged in a palindromic manner. These Spacers play a major role in bacterial immunity as they store the memory of the sequences from all the past attacks. The number of these spacer vary from specie to specie it can be from 1 to 100 (Grissa et al.2007). The protospacer adjacent motif (PAM) for streptococcus pyogenes is NGG .The PAM are present downstream of target DNA (Jiang and Doudna, 2017). Further the Cas 9 enzyme consists of two nuclease domain which induces a double stranded break as one domain binds to the target DNA strand which is homologous to the guide RNA and the other domain binds with the non-target strand (Gao et al., 2017).

\section{Remodeling CRISPR for genetic engineering}

The double stranded break efficiently induced as a result of cleavage activity of Cas 9 enzyme is the main idea behind the diversity in genetic outcomes using these technologies. After the cleavage cellular repair mechanism is activated that is of two types HDR and NHEJ. In case of non-homologous end joining (NHEJ) random DNA pieces are arranged at the end of double stranded break and then are joined by cell's own repair machinery. This method is active in all cycles of cell and is more prone to errors (Moore and Habor 1996). This process does not require homology templates as they directly ligate break ends. They can further cause indels (insertion or deletions) in the region of DSB, this can be used to achieve frameshift mutations (Waters et al., 2014). However NHEJ is quite unspecific and random process and is not efficient for single base gene knockout or insertion. Alternatively Homology directed repair occurs when sister chromatids are present. This DNA template contains the Cas 9 and gRNA along with the DNA sequence to be delivered into the cell. This method is more specific and less prone to errors (Pardo et al., 2009). However these site specific enzymes are very versatile in nature as in addition to gene editing they are also used as an artificial transcriptional factors. Scientist introduced two mutations in the cleavage domains of cas 9 nuclease which confiscated its cleavage activity but it was still able to bind to the DNA. In this way these systems were used to increase or decrease a gene expression by controlling its transcription (Bikard et al., 2013).

\section{Brief discussion of other nuclease Mega nucleases}

Starting with the mega nucleases which are also called homing endonucleases, are site specific like other restriction endonucleases. They have the ability to recognize large target DNA sequence that can be greater than 12 bp (Stoddard 2005). Discovered in 1990 , they have proved themselves to be an efficient tool for genome editing as they can generate homologous recombination (Epinat et al., 2003) and desired alterations (Arnould et al., 2007). They possess five families out of which most important one is LAGLIDADG (Stoddard et al., 2006). As they can induce homologous recombination, they were used in a number of organisms including drosophila, E.coli, mice, plants and trypanosomes (Paques 2007). These mega nucleases are very specific in nature

[Citation: Tahir, T., Ali, Q., Rashid, M.S., Malik, A. (2020). The journey of CRISPR-cas9 from bacterial defense mechanism to a gene editing tool in both animals and plants. Biol. Clin. Sci. Res. J., 2020: 17. doi: https://doi.org/10.54112/bcsrj.v2020i1.17] 
which gives them prescion and show very less level of off targeting effects, cell toxicity but changing the target of mega nucleases requires a large amount of work to obtain the results (Takeuchi et al., 2014; Thyme et al., 2014; Smith et al., 2006).

\section{Zinc finger nucleases}

As we know that zinc finger proteins are widely being used by nature (Bedis et al., 2009), so there must be some advantages of its this much use in nature that could be manipulated and reused in the form of artificial enzymes such as zinc finger nucleases. Zinc finger nucleases have been very successful in the field of genome engineering. These extraordinary enzymes consist of customizable zinc protein domain and a cleavage domain of FokI restriction endonuclease (Kim et al., 1996). A single zinc finger contains 28-30 amino acids that have a remarkable ability to functionally vary and structural flexibility to bind any triplet depending upon the form DNA sequence (Weirauch et al., 2010). These were the first of all the exonucleases that were used in a large amount (Porteus and Carroll 2005; Urnov et al., 2010) This genome editing artificial endonuclease has been successfully used in a number of organisms including maize (Shukla et al., 2009) Drosophilla (Beumer et al., 2008) rat (Geurts et al., 2009) most importantly ZFN are in clinical phase trial 2 for the treatments of AIDS proving themselves to be helpful in gene therapy (Cannon et al., 2011). But in spite of all these pros, there are always some limitations associated with a technology and as for ZFNs it is their off target effects (Gabriel et al., 2011; Pattanayak et al., 2011). They are also difficult to construct as compared to more recent and advanced gene editing techniques.

\section{TALENS}

Next came the TALENS, these are the proteins found in a bacteria called Xanthomonas that is toxic to plants as it infects them (Moscou et al., 2009; Botch et al., 2009). TALENs and ZFNs are a bit common in nature as they share some similar features, for instance a cleavage domain of FokI is found in both (Kim 2014). In addition to nuclease domain TALENs consist of a TALE DNA-binding region, which is a repeating unit having about 34 amino acids. The connection between the target DNA and the recognition domain is made possible by the repeat valuable diresidues that are the amino acids present at $12^{\text {th }}$ and $13^{\text {th }}$ position (Boch et al., 2009; Moscou and Bogdanove 2009).This exceptional nature and TALEs ability to recognize DNA length of $12-20 \mathrm{bps}$ give them specificity in genome editing (Guilinger $e t$ al., 2014). After some research on these molecular scissors, it came into light that these are more specific in nature and shows less off target effects
(Wang et al., 2015). Another quality of them making them more acceptable than ZFNs is that there is no need of directed evolution for them thereby saving a lot of time and experience of combining an enzyme to make it functional (Mussolino et al., 2014).

\section{Why CRISPR is preferred over others?}

Due to so many reasons CRISPR has replaced ZFN and TALENS. At number of times CRISPR systems have proved themselves more advanced and trustworthy over other techniques (Sander and Joung 2014). For instance ZFNs and TALENs require a customizable protein which will guide them to the target site. The designing and engineering of this protein is complex, time taking and expensive. On the other hand CRISPR depends only on the engineering of short guide RNAs (Sternberg et al., 2014). Multiplex gene changing is also very difficult using other two techniques as specific proteins are needed for each gene but by using CRISPR systems multiple gene editing is handy as only many guide RNAs are to be delivered in the cell (Campa et al., 2019). Additionally there is this fact that both ZFNs and TALENs work as a dimer to generate a double stranded break at the target site, this can be a problem as loading capacity of some of the vectors is less, so their delivery can be a great hurdle. However the delivery of CRIPSR systems is more obstacles free (Wu et al., 2010).

\section{First application of CRISPR in human beings}

Previously, genome editing was labor intensive; it could take months, costly and often limited to labs only under the supervision of experts. But now with the emergence of nucleases and advanced gene editing technologies which are friendly, cost effective and takes only weeks, it has become possible to delete the genes, (Lee et al., 2010) insert the genes (Moehle et al., 2007), replacing the faulty genes (Ran et al., 2013) and even rearrangement of chromosomes (Torres et al., 2014). Experiments using CRISPR started occurring on other mammals excluding humans. Because experimenting on human beings is always a risky thing to do. In early 2018 a Chinese scientist, Dr. He Jiankui started experimenting to produce babies from embryos that were genetically edited. These were the babies with modifications against HIV. HJ named them Lulu and Nana, In this case a specially constructed CRISPR was injected into the embryo, whose aim was to cause a 32-bpdeletion in a gene called CCR5.According to Dr. HJ this deletion would cause a nonfunctional CCR5 protein and it would be impossible to contract with AIDs (Antonio Regalado:2019). This sounds great but there are a lot of risks and concerns associated with the procedure as it has been reported that the efficiency rate using CRISPR is only $15 \%$ for the for 
a single gene correction (Liang et al., 2015). One of the major drawbacks using CRISPR editing technique is its off targets effects and it has been reported by researchers that this can cause disabilities and unfortunately can even cause cancer in some cases (Kim et al., 2015; de Miguel Beriain and del Cano, 2018). This means that the doctor himself knew all the possible side effects of these experiments but did not fully make the parents aware. In short this technique is not fully safe to be experimented on reproductive cells.

First application of CRISPR in plants

In august 20128 brief reports on the application of CRISPR system were published (Nekrasov et al., 2013; Jiang et al., 2013), One of them included observation on transgenic rice that was intentionally mutated to increase the product and growth. However the researchers later revealed that the mutation on the particular gene was successful by using the Cas9/sgRNA system (Miao et al., 2013; Zhang et al., 2014; Wolt et al., 2016). The plant model species that were used with CRISPR were Arabidopsis Heynh., Oryza L., and Nicotiana L. (Jiang et al., 2013; Shan et al., 2013; Xie and Yang, 2013). However CRISPR gene editing in plants have shown all type of plants problem solved from herbicide resistance to industrial consumption, from increased yield to crop betterment and at the last increased resistance to both biotic and abiotic stresses (Modrzejewski et al., 2019).

\section{Limitations of CRISPR and the ways in which they were improved}

As we know CRISPR is under the spotlight nowadays but there are a number of factors that influence its activity. And it is important to consider these factors in order to use this technique for in vivo human gene therapy because that is a delicate procedure.

\section{Site selection for targeted DNA}

Crispr/cas9 has the ability to recognize and select 23 bp of nucleotides that contains a PAM sequence on either templates of DNA. In case of SpCas9 this PAM sequence is said to occur after every $8 \mathrm{bp}$ on an average estimation (Ramakrishna et al., 2014). This PAM motif is specific for every species, as in case of Neisseria meningitides PAM sequence is appeared to be 5'-NNNNGATT-3' (Jiang et al., 2013; Ma et al., 2014). This feature shows a greater flexibility and higher specificity in site selection which will gradually increase with the discovery of new Cas 9 with different PAM pattern. However many reports have revealed that this is not as simple and easy as it appears to be. One report even suggests that CRISPR is not as specific as ZFNs and TALENS because it can target a shorter sequence. Hence greater the target sequence greater will be the specificity (Cradick et al., 2013).

\section{Off target cleavage}

Cutting outside the target sequence is caused by the sgRNA, Cas9 protein has no role in it but still if we improve the cas 9 protein it can reduce these effects. The journey of improving the Cas9 system has led to mutant Cas9 systems. One of this system includes the distorting of the cas 9 protein in such a manner that it only produces single stranded breaks. Then the 2 nickase enzymes (CRISPR/cas9) are used to surround the target site as one binds with the forward DNA sequence and the other with the reverse DNA sequence. In this way double stranded breaks are induced with the help of nicks. The single stranded breaks produced by off target cutting are then fused together simply by the help of DNA ligase. This mutant system when used in mammalian cells decreased off target cleavage to three folds with little to no reduction in on target efficiency (Mali et al., 2013; Ran et al., 2013; Cho et al., 2014). Another mutant system includes the joining of Cas9 with TALEs that have the ability to recognize and bind to any target site with improved specificity and reduced off target effects (Bolukbasi et al., 2015). Additionally, these mutant cas9 proteins are intentionally designed to weaken the joining of the Cas9 with target DNA strand (Kleinstiver et al., 2016) or the non-target DNA strand (Slaymaker et al., 2016) meanwhile keeping the strong on-target cleavage which is the sole purpose to reduce the unwanted DNA contacts.

\section{Frequency of HDR}

After a double stranded break, there are very less chances of a homology directed repair in mammalian cells and more chances of nonhomologous end joining, proved through an experiment in mice where Cas9 based gene editing revealed that the rate of occurrence of NHEJ associated repair was $20-60 \%$ while of HDR was only $0.5-20 \%$, even in the presence of sister chromatids, there are more chances of NHEJ repair mechanism occurring while using CRISPR system (Maruyama et al., 2015). With the passage of time many new methods have been adopted to enhance the use of HDR and suppress the efficiency of NHEJ because it is more prone to errors and for that purpose small suppressor molecules of NHEJ are used (Yu et al., 2015) gene silencing is being done to prevent the expression of a particular gene (Chu et al., 2015) cell cycles are being adjusted or harmonized (Lin et al., 2014). These inhibitors of NHEJ are very effective as the most common; Scr7 has shown increase in rate of HDR to up to 19 folds in case of CRISPR based editing (Vartak \& Raghavan, 2015). But these suppressors may have a 
toxic effect on host cells so to overcome this chemical suppression, alternative ways are being studied like synchronizing cell into cell cycles (late $\mathrm{S}$ phase and G2 phase) where HDR can occur (Lin et al., 2014).

\section{Action of cas9}

Each cas9 protein from different species have different activity and a specific PAM sequence. Thus selection of a specific Cas 9 is very important as it plays a great role in efficient gene editing. Such cas9 proteins are identified in a number of species including Staphylococcus aureus (SaCas9) (Ran et al., 2013) and S. thermophiles (St1Cas9) (Kleinstiver et al., 2015). Cas9 must be transferred to nucleus for the improved activity and for this a (NLS) nuclear location signal is attached to the Cas 9 protein. This has shown improved DNA cutting activity (Shen et al., 2013). Another trick to increase the cleavage activity is to enhance the single guide RNA (sgRNA) concentration to Cas9 protein (Kim et al., 2014). But if increased outside the limit, it may become a cause of off-target cutting (Fu et al., 2013). The catalytic activity of Cas9 is low when we compare it to other enzymes (Jinek et al., 2012). But this doesn't mean that it is not useful, this feature can be beneficial for a number of things like gene suppression/activation and short term gene editing with less off target effects. But not required for other applications where catalytic activity is the sole purpose.

\section{Some advanced CRISR systems}

Keeping in view the limitations of CRISPR, scientists developed some enhanced versions of CRISPR to increase their specificity and efficiency.

\section{CPF1 (Cas12a)}

These class 2 CRISPR systems including Cas9 and Cas12a share a number of common features that to generate a double stranded break they both rely on RNA molecules (Fonfara et al., 2016). But Cas12a recognizes its target site with the help of a single RNA (CrRNA) molecule in comparison to Cas9 that uses CrRNA:TracrRNA. The cuts produced using CPF1 have sticky ends while that of Cas9 produces blunt ends with no overhangs (Zetsche et al., 2015).Lastly Cas9 has the ability to recognize PAM sequences that have more guanosine, on the other hand Cas12a recognizes PAM sequence rich in thymine (Gao et al.2017). After some reports it was declared that Cas12a show less off target effects and are more specific in nature which is a major plus point in field of genome engineering (Kim et al.2016) Cpf1 has been successfully used for genome editing in plants rice and tobacco in the year 2016 (Endo et al., 2016). The simplicity and specificity of these tools make them very important to be used in base manipulation, multiplex gene targeting (Bayat et al.,
2018) and also this has been used in clinical trials which is a major achievement (Li et al., 2020).

Cas9n

As described earlier there are some limitations of CRISPR-Cas9 system just like it does not have important NHEJ components, therefore when used in some bacteria it may cause death after cleavage. In such cases we use a mutant of Cas9 called Cas9 nikase (Xu et al., 2015). Cas9 has two sites for cleavage but if we replace one of the sites with a single amino acid it produces Cas9n which is capable of inducing a single stranded cut on the target site (Cong et al., 2013). These mutant tools have proved themselves in the long run due to a number of reasons, the first one being their high efficiency, they are easy to construct, are pocket friendly and does not require a lot of time in construction (Jiang et al., 2013; Ran et al., 2013). Lastly they are being used to reduce the off target effects by using a double nicking technique (Shen et al., 2014).

\section{Cas13a (C2c2)}

Cas13a is another achievement in the path of CRISPR editing technology. It belongs to CRISPR class 2 system and its cleavage activity depends upon two domains known as HEPN (Abudayyeh et al., 2016). The common feature of Cas13a and Cas12a is the ability to target and edit multiple loci due to its own single crRNA template (Abudayyeh et al., 2017). This tool can be utilized to control post transcriptional suppression (Elbashir et al., 2001). When compared with RNA interference processes Cas13a is more efficient and more specific (Abudayyeh et al., 2017). As a result of alternative splicing DNA is split into many isoforms which are affected when targeted with CRISPR, but with Cas13a it is possible to target and study the task of single isoforms without affecting others (Mahas et al., 2018). Similarly there are so many other novel and enhanced systems of CRISPR to overcome the drawbacks.

\section{Delivery of CRISPR into the cells}

This step for successful genome editing is very important as the cells to be altered must receive these CRISPR systems in order to get modified. For this purpose there are a number of methods out of which some are more successful for research work and some are more beneficial for therapeutic and clinical use.

\section{Microinjection}

This is a physical method of delivery having efficiency up to $100 \%$ (Horii et al., 2014). It requires a microscope and $0.5-5.0 \mu \mathrm{m}$ diameter glass needle which pierce the cell membrane and the material is delivered directly into the target site of the cell but while doing so it also damages the cell and it can 
only infect one cell at one time which makes it very time consuming and laborious (Zhang et al., 2008). Microinjection is best suited for in vitro and ex vivo applications.

\section{Electroporation}

It is another traditional method of delivery that uses electrical current that temporarily generates nanometer pores in the membrane to make it permeable so that the material could enter the cell. While other delivery techniques depend upon cell type, this technique is less dependent on it. It is mostly used for in vitro work. As the procedure sometimes require high voltage current therefore it is not suitable for in vivo. Multiple cells can be edited using electroporation at one time (Kaneko et al., 2014). Because of its readily available sources in lab and high efficiency this technique promises a continued use for efficient delivery of CRISPR/Cas9.

\section{Hydrodynamics}

It is also a physical means of in vivo delivery, mostly enriched for liver cells (Yin et al., 2014). It uses a large volume of CRISPR/Cas9 editing system quickly injected into the blood stream of an animal, This rapid action causes an increase in hydrodynamic pressure due to which permeability of the cell membrane is enhanced for the time being and it allows the entry of the desired material. Mostly tail vein of the mice is preferred to be injected. The simplicity of this technique makes it a desirable method and it has proved itself a number of times including in vivo correction of Fah in mouse liver cells (Yin et al.2014).Then later Guan repaired hemostasis in treated mice, it is a condition in which the blood is stopped to flow out of the damaged vessel (Guan et al., 2016). Work on hepatitis B infected mice has also been done using hydrodynamic delivery method to stop the division and expression of the virus (Zhen et al., 2015). Regardless of these successful applications of this method, it is still not considered to be used in clinical works as it can cause some difficulties including stopping of the heart, enlargement of the liver and increase in blood pressure (Suda et al., 2007;Bonamassa et al., 2011). Transfection rates are low for this type of delivery and only some type more precisely liver cells are more capable of successful delivery.

\section{Viral Vectors:}

Previous physical methods discussed cannot be used in human gene therapy because they are less efficient and they are imperfect (Valsalakumarit et al., 2013). So we have other options of delivery that are:

\section{Adeno-associated viruses (AAV)}

As viruses can be DNA or RNA based, this one is single stranded DNA based virus that has been broadly utilized for gene therapy (Daya and Berns, 2008; Samulski and Muzyczka, 2014).These vectors are being used for multiple gene editing to study gene function in vivo (Swiech et al., 2015). It can infect many cells with distinctive specificities. The thing that makes AAV so special means of delivery is that they are not reported to cause any disease in human beings and also they are very efficient in their work that they do not give rise to innate or adaptive immune response or any sort of linked toxicity (Daya and Berns, 2008). AAV are so flexible that their function can be seen in in vitro, ex vivo, in vivo. It has a unique feature that the genomic material delivered through AAV can exist in two forms in the host, either directly inserted into the DNA after some modifications or outside the DNA into the cell (Deyle and Russell, 2009). The genomic material that could be packed inside the AAV particle is only 4.5-5 kb (Wu et al., 2010), which makes the packaging quite challenging but for now there are so many ways developed to adjust the packaging.

\section{Lenti (LV) and adeno viruses (AdV)}

LV and ADV are quite different from each other but the main reason they are being described under the same heading is that their way of delivering Cas9 system is quite similar. The major advantage of using LV or Adv delivery systems over AAV is that they have additional packaging space due to their large particle size that is $80-100 \mathrm{~nm}$ while of AAV is only $20 \mathrm{~nm}$. This feature allows them to adjust and carry large insertions. These methods of delivery are being used by several groups such as for gene silencing (Voets et al., (2017), moreover (Kabadi et al., (2014) made a different combination of lentivirus/CRISPR Cas9 that has the possibility to be used for delivery in invivo. Viral vectors including LV are used to screen the function of genes more specifically they identified the genes that are important for cell death induced by West-Nile-Virus (Ma et al., 2015).These viral vectors have great applications in clinical studies but there are a number of obstacles in their way like they evoke immunogenicity (Follenzi et al., 2007; Ahi et al., 2011). Additionally there are chances of off target effects and cell damage (Bestor, 2000; Papapetrou and Schambach, 2016). So they must be handled with care when using for genome editing.

\section{Non viral-vectors}

There are so many non-viral vector delivery methods that are very efficient in replacing the physical and viral methods some of them are as under.

\section{Lipid nanoparticles}

They are also known as liposomes. These particles exhibit a major advantage as like other non-viral methods that they do not contain viral components, 
therefore they do not have safety issues or they do not give rise to immunogenicity. They can be used for ex vivo, in vivo and in vitro experiments giving a wide range of applications. While delivering CRISPR/Cas9 there are two ways of using liposomes either as delivering Cas9 and single guide RNA as genetic material which will just be like microinjection in result (Yin et al., 2016) or as ribonucleoprotien complexes that contains Cas9 and SgRNA which has proved successful quite a times (Wang et al., 2016). In spite of all this when the nanoparticle has passed the surface of cell its translocation to the nucleus is quite a problem because in the passage it may come across the lysosomal pathway that will cause the degradation of the lysosome material which is a failure therefore this method of delivery has very less efficiency. But they can always be used after some improvement.

\section{Gold nanoparticles}

Another prospect for delivering ex vivo, in vivo and in vitro includes the use of AuNPs which when joined with Cas9:SgRNA ribonucleoprotiens make a complex that increases the efficiency rate of delivery up to $30 \%$ for causing the needed mutation (Mout et al., 2017), This method of delivery was also used in a mice who had Duchenne muscular dystrophy (DMD) in which the muscles are weakened due to changings in a protein called dystrophin. The gene responsible for this mutation was corrected to $5.4 \%$ after using this technique of delivery and also there was restoration of drystrophin gene expression (Lee et al., 2017) Now for the importance these particles are inert and the will not initiate any sort of immune response and are always a very good alternative to viral vectors.

\section{DNA nanoclew}

it is a distinctive technique for delivering CRISPR system but it special as it is not viral and only requires repeating DNA and PEI (polymer polyethylenimine), it came into existence by (Sun et al., 2014), A DNA nanoclew is just like a ball of yarn which is rolled on its own and joined together with the help of palindromic sequences. It has only been applied in in vitro being a new technique. When it was combined with RNP it showed $36 \%$ efficiency in an experiment performed in 2015 (Sun et al., 2015).

\section{CRISPR component delivery in plants}

CRISPR-Cas9 constructs can be delivered to explants using Agrobacterium mediated gene transfer in which the vector consisting of Cas 9 protein and guide RNA is introduced into the Agrobacterium tumefaciens (Shan et al., 2018). Another method of delivery that is used is particle bombardment (Liu et al., 2019). Both systems have advantages and drawbacks but
Agrobacterium infection is the most used one to obtains transgenic crops due to its simplicity and low copy number integration but it may cause cell death and browning of the plant, On the other hand particle bombardment technique is expensive which limits its use but it can infect a greater number of genotypes with in a specie as compared to agrobacterium infection (Altpeter et al., 2016). Furthermore viral vectors have also been used to deliver CRISPR machinery into transgenic plants (Ali et al., 2015). Cas9 can be delivered in a plant cell in the format of DNA, mRNA or proteins. Each one of them has their own positivities and negativities. For instance DNA form is low cost and once the DNA is integrated it becomes stable. But both on target and off target rates are high of this method. If we deliver it in the form of mRNA, there are chances that the mRNA may be degraded in the way and it is also not stable after integration, but to produce Cas 9 protein from mRNA is a very quick process. At the end ribonucleo-proteins can be injected directly (Woo et al., 2015). This method of delivery can give rise to directly the genome editing steps without wasting time. But defense mechanism may be active in eukaryotic cells after direct introduction of bacterial proteins through this method secondly the size endonuclease size is large which may become a hindrance in the pathway of introduction into the plant cell (Glass et al., 2018). In agricultural approaches both mRNA and nucleoprotein forms are suitable as compared to DNA form of delivery because it introduces transgenes into the plant.

\section{Application in plants}

\section{Use of CRIPSR in Plants to combat biotic stress}

Every year a great amount of crop yield is lost due to biotic and abiotic stresses. In order to fulfill our need of food we use engineered plants that have the ability to fight against bacteria, viruses, fungus, nematodes, insects and other pathogens that make up the biotic stress of a plant. There is an estimated average global yield loss of 11 to $30 \%$ just due to these pathogenic plant microbes and because of insect attack on plants (Savary et al., 2019) and an average 10-15\% damage caused by alone viruses (Van et al., 2008). So since the very beginning scientists have been trying to develop new ways to introduce resistant crop varieties in the environment and for this purpose they used some conventional techniques including cross breeding, hybridization, biological and chemical mutagenesis (Langer et al., 2018), but there were several problems with these methods such as chances of undesired or non-targeted modifications and the process of screening required a lot of time and labour work. Conventional techniques were followed by genetically modified and genetically engineered

[Citation: Tahir, T., Ali, Q., Rashid, M.S., Malik, A. (2020). The journey of CRISPR-cas9 from bacterial defense mechanism to a gene editing tool in both animals and plants. Biol. Clin. Sci. Res. J., 2020: 17. doi: https://doi.org/10.54112/bcsrj.v2020i1.17] 
crops which were again problematic. In last 10 years the hard work of scientists has finally been paid with

the introduction of CRISPR

Table 1A list of some examples of biotic stress pathogen that has been edited using CRISPR

\begin{tabular}{lllll}
\hline Pathogen & Disease & Host & Target Gene & References \\
\hline $\begin{array}{l}\text { Oidium neolycopersici } \\
\text { powdery } \\
\text { mildew } \\
\text { fungal }\end{array}$ & Tomato & Deletion in MLO1 locus & Klimek-Chodacka et \\
al., (2018)
\end{tabular}

CRISPR has shown exceptional and promising work in developing successful biotic resistant crops in such a short period which was not possible by old techniques

\section{CRISPR and abiotic stress in plants}

Similarly this site specific genome editing technique has been successfully used in 20 crop species (Ricroch et al., 2017) to either increase their yield of to make them resistance to biotic or abiotic stresses. Abiotic stress is the most serious obstacle in the development and production of agriculture. Abiotic stress involves a number of genes and mainly environmental conditions (Bhat et al., 2016). These environmental factors include drought, salinity, cold and heavy metals. Drought and salinity are the major contributors in effecting the crop productivity as they affect 40 and $7 \%$ of the global area (Trenberth et al., 2014). These abiotic stresses affect all the major and essential processes of a plant including photosynthesis, protein building, stomata passage and the rate at which transpiration occurs (Zhang X. et al., 2014; Zhu et al., 2016; Elferjani and Soolanayakanahally, 2018). Here is a list of plants that have been modified using CRISPR to make them adopt to these stress conditions.

Table 2. List of CRISPR mediated gene editing of abiotic stress genes in crops

\begin{tabular}{llll}
\hline Crop & Abiotic stress & targeted gene & References \\
\hline Maize & Drought tolerance & ARGOS8 & Shi et al., (2017) \\
Corn & Drought tolerance & ARGOS8 & Shi et al., (2017) \\
Arabidopsis & enhanced & OST2/AHA1 & Osakabe et al., (2017) \\
Stomata responses & & \\
Tomato & Drought Tolerance & SIMAPK3 & Wang et al., (2017) \\
Rice & salinity tolerance & OsRR22 & Zhang et al., (2019) \\
OsNAC041 & \multicolumn{2}{c}{ Bo et al., (2019) } & \\
Wheat & Drought tolerance & TaDREB3 & Kim et al., (2019) \\
TaDREB2 & & & \\
\hline
\end{tabular}

\section{Using CRISPR to improve plant nutrition and yield}

After fighting with biotic and abiotic challenges in plants the next big challenge was to improve the crop yield to feed the ever increasing population. There is reported to be an increase in the nutrition value of sorghum and wheat under the assistance of CRISPR (Li et al., 2018a; Zhang et al., 2018b). In 2017 a batch of scientists worked together and they were able to mutate the promoter region of some quantitative genes of tomato under CRISPR that

[Citation: Tahir, T., Ali, Q., Rashid, M.S., Malik, A. (2020). The journey of CRISPR-cas9 from bacterial defense mechanism to a gene editing tool in both animals and plants. Biol. Clin. Sci. Res. J., 2020: 17. doi: https://doi.org/10.54112/bcsrj.v2020i1.17] 
resulted in so many improved traits including better fruit shape and size that the non-mutated (RodríguezLeal et al., 2017). From this study we have the idea

Table 3. Some examples of CRISPR edited crops to enhance crop yield and quality

\begin{tabular}{|c|c|c|c|}
\hline Plant & Trait improvement & Targeted gene & References \\
\hline Apple & \multirow{3}{*}{ non browning } & \multirow{3}{*}{$\begin{array}{l}\text { Polyphenol oxidase } \\
\text { (PPO) genes }\end{array}$} & Halterman et al., (2015) \\
\hline Mushroo & & & Nishitani et al., (2016) \\
\hline Potatoes & & & Waltz et al., (2016) \\
\hline Rice & increased seed size & GW2, GW5, TGW6 & Xu et al., (2016) \\
\hline wheat & increased seed size & TaGW2 & Wang et al., (2018) \\
\hline Banana & increased quality & $\begin{array}{l}\text { RAS-PDS } 1 \\
\text { RAS-PDS } 2\end{array}$ & Zhang et al., (2018) \\
\hline Rice & increased cooking & Waxy gene & Kaur et al., (2018) \\
\hline Rice & $\begin{array}{l}\text { Increased nutrition } \\
\text { increased amylose } \\
\text { Synthesis }\end{array}$ & SBEIIb & Zhang et al., (2018) \\
\hline Wheat & low gluten & family $\alpha$-gliadin & Sun et al., (2017) \\
\hline Soybean & high yield & FAD2-1B , & Sanchex-Leon et al., (2018) \\
\hline Maize & $\begin{array}{l}\text { Improved level of oleic acid } \\
\text { increased level } \\
\text { Of healthy tryptophan } \\
\text { And lysine }\end{array}$ & $\begin{array}{l}\text { FAD2-1A } \\
\text { PPR and RPL }\end{array}$ & $\begin{array}{l}\text { Kim et al., (2017) } \\
\text { Qi et al., (2016) }\end{array}$ \\
\hline
\end{tabular}

that plants traits can be enhanced that just need a little push by utilizing CRISPR.
These are a very few success stories of using CRISPR and with the seen progress there are so many chances of more to come.

Industrial applications of CRISPR

As we know that biological industries require microorganism for their various processes. In order to enhance the efficiency of these microorganisms, modification was done using laborious and time taking methods. To the surprise of scientists came CRISPR as a gift to solve most of their problems with gene editing. Here is a little summary of using them to manipulate important industrial bacterial, yeast and filamentous fungi cells.

\section{In Bacteria}

E. coli is one of the well-known and significant strains used to produce many chemicals drugs and other useful biofuels in the industry. With the passage of time there is a great advancement in every field which has enabled us to increase the yield and revenue of the desired products from $E$. coli (Dellomonaco et al., 2010). For instance CRISPR was availed to uplift the flavonoid production (flavonoids are strong antioxidant with qualities of anti-inflammation and immunity). It was done so by finely adjusting and refining the metabolic systems of cell like TCA cycle and glycolysis. It was proved by this experiment that CRISPR can be used in this way without interfering with the cell's normal growth (Wu et al., 2015). In another example for the production of n-butanol, the expression of four of the cell's own gene (pta, frdA, ldhA, and adhE) was reduced using guided CRISPRi system. N-butanol is needed for the synthesis of ethanol, acetate, and succinate. These are important biofuels (Kim et al., 2017). Other species of bacteria were also facilitated by CRISPR for example solventogenic Clostridium. These strains were not efficiently engineered due to some lacking like less understanding of its biological pathways and structure, secondly transformation rate was also low (Pyne et al., 2014; Bruder et al., 2016). During 2017 CRISPR engineering was done in a strain of Clostridium for Increased level of butanol. The butanol level reached to $19.0 \mathrm{~g} / \mathrm{L}$ which was the highest record ever occurred through batch fermentation (Wang et al., 2017). Furthermore our little star was also able to produce succinate (chemical) in huge amount in Synechococcus elongates (Li et al., 2016).

In yeast and fungi

Similarly yeasts are also widely used for the production of great number beneficial products like enzymes, artificial food flavoring agents, chemicals, inexhaustible biofuels and in the production of biopharmaceuticals (Raschmanova et al., 2018). Yeasts have a tough body which enables them to even live in unsurvivable environments. For the production of biopharmaceuticals eukaryotic post translational modifications are very important but bacteria lacks such modifications, so yeast can be used instead (Thomas et al., 2013). CRISPR was applied in many yeast species including Schizos 
accharomyces pombe. The purpose of this modification was to achieve more efficient promoters. Jacob et al was successful in achieving a high efficiency of $98 \%$ in this process and resulted in highly efficient knockout (Jacobs et al., 2014). Once again fungi is used to make many pigments, organic acids polyunsaturated fatty acids and so many other things (Dufossé et al., 2014; Ji et al., 2014) But there were some problems with its usage in industry Firstly the passage of tool across the fungal cell wall was a big challenge and even if the gene editing tool was delivered, editing efficiency was low and thirdly it was a laborious work that required a lot of time. However it was all until the discovery of CRISPR. CRISPR has been implemented successfully in Trichoderma reesei (Hao and $\mathrm{Su}, 2019$ ) and in Aspergillus fumigatus which achieved a high efficiency in gene editing of $100 \%$ (Zhang et al., 2016). This once again showed the greatness of CRISPR as a power full genome editing tool.

\section{Oncology and CRISPR}

There are number of genetic and epigenetic factors involved in the cause of malignant cell formation. These factors can be tumor suppressers, cancer causing genes, chemo resistant genes and control loci. CRISPR appears to be helpful and promising in this matter because it possess the ability to correct such mutations and cure cancer (White and Khalili et al., 2016). Scientist are successful by using targeted CRISPR systems to generate cell lines and animal models for different type of cancers by either deleting or inserting the oncogenes or tumor suppresser genes (Platt et al., 2014). These animal models are also used to study the effect of specific genes in a disease (Chen et al., 2016). The most widely used animal model is the mice because of its exceptional qualities over other. It takes lesser time to generate mutants it is cheap to use and it is applicable in large scale mutagenesis studies (Hsu et al., 2014). Moreover scientists have been fruitful to generate cell lines for lung cancer (Choi and Meyerson et al. 2014), liver cancer (Xue et al., 2014) and pancreatic cancer (Chiou et al., 2015). CRISPR can target the oncogenes like receptor tyrosine kinase Erb2 involved in causing tumor cells (Brown and cooper et al., 1996). According to recent researches cas9 was employed to knockdown or repress MDR1 in osteosarcoma cells. As a result there was reduction in resistance to chemotherapeutic agents which is a good sign (Liu et al., 2016). In another experiment performed in vivo in mice, NANOG and NANOGP8 genes were targeted by CRISPR. These genes are take part in causing prostate cancer. However the end result was reduced tumorigenic concentration (Kawamura et al., 2015).

\section{Terminating viral cells}

This feature show the worth of CRISPR more as it can be implemented to destroy the replication system of virus, thus fighting with the viral diseases. It has been used to target Hepatitis B virus (HBV) (Zeisel et al., 2014). Researchers have been fortunate in targeting with Cas 9 both inside and outside the living organism and producing long term reduction in viral capacity and less production of antigen that is disease causing (Kennedy et al., 2015). Through some other tests researchers were able to knockout part of (HIV-1) from human CD4+ T-cells (Kaminski et al., 2016). However most of the cases are in clinical trials.

\section{Fighting with Genetic diseases}

Apart from combating with cancer, viral and bacterial infections, CRISPR are used to eliminate and target such inherited genes that causes disorders. For instance in an eye disease named as Retinitis pigmentosa in which the individual losses his sight due to the disruption of photoreceptors is successfully being targeted and mutated with RPGR gene. This gene in healthy individuals expresses protiens that are involved in vision building factors. It is a hope for all the blinded patients of Retinitis (Bassuk et al., 2016). There is a great room for CRISPR editing in other diseases because of its stable qualities. Other disease like cystic fibrosis that occurs a result of mutation in CFTR gene (Kerem et al., 1989) or sickle cell are long lasting disease which shorten the life span of the one carrying the genes (Lanzkron et al., 2013). With the help of CRISPR scientist were able to edit intestinal stem cells from the patient of cystic fibrosis outside its own living cell and repair their function (Schwank et al,. 2013). In case of sickle cell with HDR mediated Cas9 $\mathrm{Li}$ and his coworkers have edited the disease causing genes in pluripotent stem cells as a result no noticeable off targeting was seen (Li et al,. 2016). Further clinical trials are under process for sickle cell.

\section{Conflict of interest}

The authors declared absence of any type of conflict of interest for manuscript publication.

\section{References}

Abudayyeh O.O., Gootenberg J.S., Essletzbichler P., Han S., Joung J., Belanto J.J., Verdine V., Cox D.B.T., Kellner M.J., Regev A., et al. (2017). RNA targeting with CRISPR-Cas13. Nature. 550:280-284.

Abudayyeh O.O., Gootenberg J.S., Konermann S., Joung J., Slaymaker I.M., Cox D.B.T., Shmakov S., Makarova K.S., Semenova E.,

[Citation: Tahir, T., Ali, Q., Rashid, M.S., Malik, A. (2020). The journey of CRISPR-cas9 from bacterial defense mechanism to a gene editing tool in both animals and plants. Biol. Clin. Sci. Res. J., 2020: 17. doi: https://doi.org/10.54112/bcsrj.v2020i1.17] 
Minakhin L., et al. (2016). C2c2 is a singlecomponent programmable RNA-guided RNAtargeting CRISPR effector. Science 353:aaf5573.

Ahi YS, Bangari DS, Mittal SK. (2011). Adenoviral vector immunity: its implications and circumvention strategies. CGT 11:307-20.

Ali, Z., Abul Faraj A., Li L., Ghosh N., Piatek M., Mahjoub A., Aouida M., et al. (2015). Efficient virus mediated genome editing in plants using the CRISPR/Cas9 system. Molecular Plant 8: 1288-1291.

Altpeter, F. , Springer N. M., Bartley L. E., Blechl A. E., Brutnell T. P., Citovsky V., Conrad L. J., et al. (2016). Advancing crop transformation in the era of genome editing. The Plant Cell 28: 1510-1520.

Antonio Regalado, China's CRISPR twins might have had their brains inadvertently enhanced, mit tech. rev (Feb. 21, 2019), https://www.technologyreview.com/s/612997/t he-crispr-twins-had-their-brains-altered/ (accessed Mar. 12, 2019)

Arnould, Sylvain; Perez, Christophe; Cabaniols, Jean-Pierre; Smith, Julianne; Gouble, Agnès; Grizot, Sylvestre; Epinat, Jean-Charles; Duclert, Aymeric; Duchateau, Philippe (200708-03). "Engineered I-CreI derivatives cleaving sequences from the human XPC gene can induce highly efficient gene correction in mammalian cells". Journal of Molecular Biology. 371 (1): 49-65.

Badis, G., Berger, M.F., Philippakis, A.A., et al. (2009). Diversity and complexity in DNA recognition by transcription factors. Science. 324(5935):1720-1723.

Bao A., Burritt D. J., Chen H., Zhou X., Cao D., Tran L. P. (2019). The CRISPR/Cas9 system and its applications in crop genome editing. Crit. Rev. Biotechnol. 39, 1-16.

Barrangou, R., Fremaux, C., Deveau, H., Richards, M., Boyaval, P., Moineau, S., Romero, D.A., Horvath, P. (2007). CRISPR provides acquired resistance against viruses in prokaryotes. Science 315: 1709-1712.

Barrangou, R., Marraffini, L.A. (2014). CRISPR-cas systems: Prokaryotes upgrade to adaptive immunity. Mol. Cell. 54:234-244.

Bassuk, A.G., Zheng, A., Li, Y., Tsang, S.H. and Mahajan, V.B., (2016). Precision medicine: genetic repair of retinitis pigmentosa in patient-derived stem cells. Scientific reports, 6 , p.19969.
Bayat, H., Modarressi, M.H., Rahimpour, A. (2018). The conspicuity of CRISPR-Cpf1 system as a significant breakthrough in genome editing. Curr Microbiol. 75(1):107-115.

Bestor TH. (2000). Gene silencing as a threat to the success of gene therapy. $J$ Clin Invest 105:409-11.

Beumer, K.J., Trautman, J.K., Bozas, A., Liu, J.L., Rutter, J., et al. (2008) Efficient gene targeting in Drosophila by direct embryo injection with zinc-finger nucleases. Proc Natl Acad Sci US A 105: 19821-19826

Bhat J.A., Ali S., Salgotra R.K., Mir Z.A., Dutta S., Jadon V., Tyagi A., Mushtaq M., Jain N., Singh P. (2017). Genomic selection in the era of next generation sequencing for complex traits in plant breeding. Front. Genet. 7:221.

Bikard D., Jiang W., Samai P., Hochschild A., Zhang F., Marraffini L.A. (2013). Programmable repression and activation of bacterial gene expression using an engineered CRISPR-Cas system. Nucleic Acids Res. 41:7429-7437.

Bo W., Zhaohui Z., Huanhuan Z., Xia W., Binglin L., Lijia Y., Xiangyan H., Deshui Y., Xuelian Z., Chunguo W. (2019). Targeted Mutagenesis of NAC Transcription Factor Gene, OsNAC041, Leading to Salt Sensitivity in Rice. Rice Sci. 26:98-108.

Boch J., Scholze H., Schornack S., Landgraf A., Hahn S., Kay S., Lahaye T., Nickstadt A., Bonas U. (2009). Breaking the Code of DNA Binding Specificity of TAL-Type III Effectors. Science. 326: $1509-1512$.

Bolukbasi, M.F., Gupta, A., Oikemus, S., et al. (2015). DNA-binding-domain fusions enhance the targeting range and precision of Cas9. Nat Methods 12:1150-6.

Bonamassa B, Hai L, Liu D. (2011). Hydrodynamic gene delivery and its applications in pharmaceutical research. Pharm Res 28:694701.

Brown, M.T., Cooperm J.A. (1996). Regulation, substrates and functions of src. Biochim Biophys Acta. 1287:121-149.

Bruder M. R., Pyne M. E., Moo-Young M., Chung D. A., Chou C. P. (2016). Extending CRISPRCas9 technology from genome editing to transcriptional engineering in Clostridium. Appl. Environ. Microbiol. 82, 6109-6119.

Campa, C.C., Weisbach N.R., Santinha A.J., Incarnato D., and Platt R.J. (2019). Multiplexed genome engineering by Cas $12 \mathrm{a}$

[Citation: Tahir, T., Ali, Q., Rashid, M.S., Malik, A. (2020). The journey of CRISPR-cas9 from bacterial defense mechanism to a gene editing tool in both animals and plants. Biol. Clin. Sci. Res. J., 2020: 17. doi: https://doi.org/10.54112/bcsrj.v2020i1.17] 
and CRISPR arrays encoded on single transcripts. Nature Methods 16: 887-893.

Cannon, P., June, C (2011) Chemokine receptor 5 knockout strategies. Current Opinion in HIV and AIDS 6: 74-79.

Chen, S., Sanjana N.E., Zheng K., Shalem O., Shi X., Scott D.A., Song J., Pan J.Q., Weissleder R., Zhang F., et al. (2015). Genome-wide CRISPR screen in a mouse model of tumor growth and metastasis. Cell. 160:1246-1260.

Chiou SH, Winters IP, Wang J, et al. (2015). Pancreatic cancer modeling using retrograde viral vector delivery and in vivo CRISPR/Cas9-mediated somatic genome editing. Genes Dev. 29:1576-1585.

Cho, S.W., Kim, S., Kim, Y., et al. (2014). Analysis of off-target effects of CRISPR/Cas-derived RNA-guided endonucleases and nickases. Genome Res 24:132-41.

Choi, P.S., Meyerson, M. (2014). Targeted genomic rearrangements using CRISPR/Cas technology. Nat Commun. 5:3728.

Chu VT, Weber T, Wefers B, et al. (2015). Increasing the efficiency of homology-directed repair for CRISPR-Cas9-induced precise gene editing in mammalian cells. Nat Biotechnol 33:543-8.

Cohen S.N., Chang A.C.Y., Boyer H.W., Helling R.B. (1973). Construction of Biologically Functional Bacterial Plasmids In Vitro. Proc. Natl. Acad. Sci. USA.;70:3240-3244.

Cong, L., Ran, F.A., Cox, D., Lin, S., Barretto, R., Habib, N., Hsu, P.D., Wu, X., Jiang, W., Marraffini, L.A., Zhang, F. (2013). Multiplex genome engineering using CRISPR/Cas systems. Science 339:819-823.

Cradick, T.J., Fine, E.J., Antico, C.J., Bao, G. (2013). CRISPR/Cas9 systems targeting beta-globin and CCR5 genes have substantial off-target activity. Nucleic Acids Res 41:9584-92.

Daya S, Berns KI. (2008). Gene therapy using adenoassociated virus vectors. Clin Microbiol Rev 21:583-93.

de Miguel Beriain I, del Cano AMM. (2018). Chapter 12 Gene editing in human embryos. A comment on the ethical issues involved. In: Soniewicka M , editor. The Ethics of Reproductive Genetics: Between Utility, Principles, and Virtues. Springer, Cham; 2018. pp. 173-183.

Dellomonaco C., Fava F., Gonzalez R. (2010). The path to next generation biofuels: Successes and challenges in the era of synthetic biology. Microb. Cell Fact. 9:3
Deyle DR, Russell DW. (2009). Adeno-associated virus vector integration. Curr Opin Mol Ther 11:442-7.

Dufossé L., Fouillaud M., Caro Y., Mapari S. A., Sutthiwong N. (2014). Filamentous fungi are large-scale producers of pigments and colorants for the food industry. Curr. Opin. Biotech. 26, 56-61.

Elbashir S.M., Harborth J., Lendeckel W., Yalcin A., Weber K., Tuschl T. (2001). Duplexes of $21 \pm$ nucleotide RNAs mediate RNA interference in cultured mammalian cells. Nature. 411:494498.

Elferjani R., Soolanayakanahally R. (2018). Canola responses to drought, heat, and combined stress: shared and specific effects on carbon assimilation, seed yield, and oil composition. Front. Plant Sci. 9, 1224.

Endo A., Masafumi M., Kaya H., Toki S. (2016). Efficient targeted mutagenesis of rice and tobacco genomes using Cpf1 from Francisella novicida. Sci. Rep. 6:38169.

Epinat, Jean-Charles; Arnould, Sylvain; Chames, Patrick; Rochaix, Pascal; Desfontaines, Dominique; Puzin, Clémence; Patin, Amélie; Zanghellini, Alexandre; Pâques, Frédéric (2003-06-01). "A novel engineered meganuclease induces homologous recombination in yeast and mammalian cells". Nucleic Acids Research. 31 (11): 2952-2962.

Follenzi A, Santambrogio L, Annoni A. (2007). Immune responses to lentiviral vectors. Curr Gene Ther 7:306-15.

Fonfara I., Richter H., BratoviÄ M., Le Rhun A., Charpentier E. (2016). The CRISPRassociated DNA-cleaving enzyme Cpf1 also processes precursor CRISPR RNA. Nature. 532:517-521.

Fu, Y., Foden, J.A., Khayter, C., et al. (2013). Highfrequency off-target mutagenesis induced by CRISPR-Cas nucleases in human cells. Nat Biotechnol 31:822-6.

Gabriel, R., Lombardo, A., Arens, A., Miller, J.C., Genovese, P., Kaeppel, C., Nowrouzi, A., Bartholomae, C.C., Wang, J., Friedman, G., et al. (2011). An unbiased genome-wide analysis of zinc-finger nuclease specificity. Nat Biotechnol 29: 816-823.

Gao L., Cox D.B.T., Yan W.X., Manteiga J.C., Schneider M.W., Yamano T., Nishimasu H., Nureki O., Crosetto N., Zhang F. (2016). Engineered Cpf1 variants with altered PAM specificities. Nat. Biotechnol. 35:789-792.

[Citation: Tahir, T., Ali, Q., Rashid, M.S., Malik, A. (2020). The journey of CRISPR-cas9 from bacterial defense mechanism to a gene editing tool in both animals and plants. Biol. Clin. Sci. Res. J., 2020: 17. doi: https://doi.org/10.54112/bcsrj.v2020i1.17] 
Gao, L., Cox D. B. T., Yan W. X., Manteiga J. C., Schneider M. W., Yamano T., et al. (2017). Engineered Cpf1 variants with altered PAM specificities. Nat. Biotechnol. 35, 789-792.

Gasiunas, G., Barrangou, R., Horvath, P., Siksnys, V. (2012). Cas9-crRNA ribonucleoprotein complex mediates specific DNA cleavage for adaptive immunity in bacteria. Proc Natl Acad Sci U S A 109:E2579-E2586.

Geurts, A.M., Cost, G.J., Freyvert, Y., Zeitler, B., Miller, J.C., et al. (2009) Knockout Rats via Embryo Microinjection of Zinc-Finger Nucleases. Science 325: 433.

Glass, Z. , Lee M., Li Y., and Xu Q.. 2018. Engineering the delivery system for CRISPR-based genome editing. Trends in Biotechnology 36: 173-185.

Grissa, I., Vergnaud, G., Pourcel, C. (2007). The CRISPRdb database and tools to display CRISPRs and to generate dictionaries of spacers and repeats. BMC Bioinform. 8:1-10.

Guan Y, Ma Y, Li Q, et al. (2016). CRISPR/Cas9mediated somatic correction of a novel coagulator factor IX gene mutation ameliorates hemophilia in mouse. $E M B O \mathrm{Mol}$ Med 8:477-88.

Guilinger, J.P., Pattanayak, V., Reyon, D., Tsai, S.Q., Sander, J.D., Joung, J.K., Liu, D.R. (2014a). Broad specificity profiling of TALENs results in engineered nucleases with improved DNAcleavage specificity. Nat Methods 11: 429435.

Halterman D., Guenthner J., Collinge S., Butler N., Douches D. (2015). Biotech Potatoes in the 21st Century: 20 years since the first biotech potato. Am. J. Potato 93: 1-20.

Hao Z., Su X. (2019). Fast gene disruption in Trichoderma reesei using in vitro assembled Cas9/gRNA complex. BMC Biotechnol. 19:2.

Horii T, Arai Y, Yamazaki M, et al. (2014). Validation of microinjection methods for generating knockout mice by CRISPR/Casmediated genome engineering. Sci Rep 4:4513.

Hunter M. C., Smith R. G., Schipanski M. E., Atwood L. W., Mortensen D. A. (2017). Agriculture in 2050: recalibrating targets for sustainable intensification. Bioscience 67, 385-390.

Hsu PD, Lander ES, Zhang F. Development and applications of CRISPR-Cas9 for genome engineering. Cell. 2014;157:1262-1278

Ishino, Y., Shinagawam H., Makinom K., Amemura, M., Nakata, A. (1987). Nucleotide sequence of the iap gene, responsible for alkaline phosphatase isozyme conversion in Escherichia coli, and identification of the gene product. J Bacteriol 169:5429-5433.

Jacobs J. Z., Ciccaglione K. M., Tournier V., Zaratiegui M. (2014). Implementation of the CRISPR-Cas9 system in fission yeast. Nat. Commun. 5:5344. 10.1038/ncomms6344

Jansen, R., van Emben, J.D.A., Gaastra, W. and Schouls L.M. (2002). Identification of genes that are associated with DNA repeats in prokaryotes. Mol. Microbiol. 43 1565-

Ji X. J., Ren L. J., Nie Z. K., Huang H., Ouyang P. K. (2014). Fungal arachidonic acid-rich oil: research, development and industrialization. Crit. Rew. Biotechnol. 34, 197-214.

Jiang W, Bikard D, Cox D, Zhang F, Marraffini LA. (2013). RNA-guided editing of bacterial genomes using CRISPR-Cas systems. Nat. Biotechnol. 31:233-239.

Jiang, F., Doudna J. A. (2017). CRISPR-Cas9 structures and mechanisms. Annu. Rev. Biophys. 46, 505-529.

Jiang, F., Doudna J. A. (2017). CRISPR-Cas9 structures and mechanisms. Annu. Rev. Biophys. 46, 505-529.

Jiang, W., Zhou H., Bi H., Fromm M., Yang B., and Weeks D. P. (2013). Demonstration of CRISPR/Cas9/sgRNA mediated targeted gene modification in Arabidopsis, tobacco, sorghum and rice. Nucleic Acids Research 41: e188.

Jiang, W., Bikard, D., Cox, D., et al. (2013). RNAguided editing of bacterial genomes using CRISPR-Cas systems. Nat Biotechnol 31:2339.

Jinek M, Chylinski K, Fonfara I, et al. (2012). A programmable dual-RNA-guided DNA endonuclease in adaptive bacterial immunity. Science 337:816-21.

Kabadi AM, Ousterout DG, Hilton IB, Gersbach CA. (2014). Multiplex CRISPR/Cas9-based genome engineering from a single lentiviral vector. Nucleic Acids Res 42:e147.

Kaminski R., Chen Y., Fischer T., Tedaldi E., Napoli A., Zhang Y., Karn J., Hu W., Khalili K. (2016). Elimination of HIV-1 Genomes from Human T-lymphoid Cells by CRISPR/Cas9 Gene Editing. Sci. Rep. 6:1-14.

Kaneko T., Sakuma T., Yamamoto T., Mashimo T. (2014). Simple knockout by electroporation of engineered endonucleases into intact rat embryos. Sci. Rep. 4:1-5.

Kaur N., Alok A., Shivani, Kaur N., Pandey P., Awasthi P., et al. . (2018). CRISPR/Cas9-

[Citation: Tahir, T., Ali, Q., Rashid, M.S., Malik, A. (2020). The journey of CRISPR-cas9 from bacterial defense mechanism to a gene editing tool in both animals and plants. Biol. Clin. Sci. Res. J., 2020: 17. doi: https://doi.org/10.54112/bcsrj.v2020i1.17] 
mediated efficient editing in phytoene desaturase (PDS) demonstrates precise manipulation in banana $\mathrm{cv}$. rasthali genome. Funct. Integr. Genomics 18, 89-99.

Kawamura, N., Nimura K., Nagano H., Yamaguchi S., Nonomura N., Kaneda Y. (2015) CRISPR/Cas9-mediated gene knockout of NANOG and NANOGP8 decreases the malignant potential of prostate cancer cells. Oncotarget. 6:22361-22374.

Kennedy, E.M., Bassit L.C., Mueller H., Kornepati A.V.R., Bogerd H.P., Nie T., Chatterjee P., Javanbakht H., Schinazi R.F., Cullen B.R. (2015). Suppression of hepatitis B virus DNA accumulation in chronically infected cells using a bacterial CRISPR/Cas RNA-guided DNA endonuclease. Virology. 476:196-205.

Kerem B., Rommens J.M., Buchanan J.A., Markiewicz D., Cox T.K., Chakravarti A., Buchwald M., Tsui L.C. (1989). Identification of the cystic fibrosis gene: Genetic analysis. Science. 245:1073-1080.

Khatodia, S., Bhatotia K., Passricha N., Khurana S. M., Tuteja N. (2016). The CRISPR/Cas genome-editing tool: application in improvement of crops. Front. Plant Sci. 7:506.

Kim D, et al. (2016). Genome-wide analysis reveals specificities of $\mathrm{Cpf} 1$ endonucleases in human cells. Nat Biotechnol. 34:863-868.

Kim D., Kim D., Alptekin B., Budak H. (2017). CRISPR/Cas9 genome editing in wheat. Funct. Integr. Genomics. 18:31-41.

Kim H., Kim J.S. (2014). A guide to genome engineering with programmable nucleases. Nat. Rev. Genet. 15:321-334.

Kim H., Kim S.T., Ryu J., Kang B.C., Kim J.S., Kim S.G. (2017). CRISPR/Cpf1-mediated DNAfree plant genome editing. Nat. Commun. 8: 14406.

Kim S.K., Seong W., Han G.H., Lee D.H., Lee S.G. (2017). CRISPR interference-guided multiplex repression of endogenous competing pathway genes for redirecting metabolic flux in Escherichia coli. Microb. Cell Fact. 16:188.

Kim, D., Bae, S., Park, J., et al. (2015). Digenomeseq: genome-wide profiling of CRISPR-Cas9 off-target effects in human cells. Nat Methods. 12(3):237-243.

Kim, S., Kim, D., Cho, S.W., et al. (2014). Highly efficient RNA-guided genome editing in human cells via delivery of purified Cas9 ribonucleoproteins. Genome Res 24:1012-9.

Kim, Y.G., Cha, J., Chandrasegaran, S. (1996). Hybrid restriction enzymes: zinc finger fusions to Fok I cleavage domain. Proc Natl Acad Sci U S A 93: 1156-1160.

Kleinstiver, B.P., Pattanayak, V., Prew, M.S., et al. (2016). High-fidelity CRISPR-Cas9 nucleases with no detectable genome-wide off-target effects. Nature 529:490-5.

Kleinstiver, B.P., Prew, M.S., Tsai, S.Q., et al. (2015). Broadening the targeting range of Staphylococcus aureus CRISPR-Cas9 by modifying PAM recognition. Nat Biotechnol 33:1293-8.

Klimek-Chodacka M., Oleszkiewicz T., Lowder L.G., Qi Y., Baranski R. (2018). Efficient CRISPR/Cas9-based genome editing in carrot cells. Plant Cell Rep. 37:575-586.

Langner T., Kamoun S., Belhaj K. (2018). CRISPR Crops: Plant Genome Editing Toward Disease Resistance. Annu. Rev. Phytopathol. 56:479512.

Lanzkron S., Carroll C.P., Haywood C., Jr. (2013). Mortality rates and age at death from sickle cell disease: U.S., 1979-2005. Public Health Rep.128:110-116.

Lee K, Conboy M, Park HM, et al. (2017). Nanoparticle delivery of Cas9 ribonucleoprotein and donor DNA in vivo induces homology-directed DNA repair. Nat Biomed Eng 1:889-901.

Lee, H.J., Kim, E., Kim, J.S. (2010). Targeted chromosomal deletions in human cells using zinc finger nucleases. Genome Res 20: 81-89.

Li A., Jia S., Yobi A., Ge Z., Sato S. J., Zhang C., et al. (2018a). Editing of an Alpha-Kafirin gene family increases, digestibility and protein quality in Sorghum. Plant Physiol. 177, 14251438.

Li B., Niu Y., Ji W., Dong Y. Strategies for the CRISPR-Based Therapeutics. Trends Pharmacol. Sci. 2020;41:55-65.

Li C., Ding L., Sun C.W., Wu L.C., Zhou D., Pawlik K.M., Khodadadi-Jamayran A., Westin E., Goldman F.D., Townes T.M. (2016). Novel HDAd/EBV Reprogramming Vector and Highly Efficient Ad/CRISPR-Cas Sickle Cell Disease Gene Correction. Sci. Rep. 6:1-10

Li H., Shen C. R., Huang C. H., Sung L. Y., Wu M. Y., Hu Y. C. (2016). CRISPR-Cas9 for the genome engineering of Cyanobacteria and succinate production. Metab. Eng. 38, 293302.

Liang, P.P., Xu, Y.W., Zhang, X.Y., et al. (2015). CRISPR/Cas9-mediated gene editing in human tripronuclear zygotes. Protein Cell. 6(5):363372.

[Citation: Tahir, T., Ali, Q., Rashid, M.S., Malik, A. (2020). The journey of CRISPR-cas9 from bacterial defense mechanism to a gene editing tool in both animals and plants. Biol. Clin. Sci. Res. J., 2020: 17. doi: https://doi.org/10.54112/bcsrj.v2020i1.17] 
Lin, S., Staahl, B.T., Alla, R.K., Doudna, J.A. (2014). Enhanced homology-directed human genome engineering by controlled timing of CRISPR/Cas9 delivery. Elife 3:e4766.

Liu, G. , Li J., and Godwin I. D.. 2019. Genome editing by CRISPR/Cas9 in sorghum through biolistic bombardment In Zhao Z. Y. and Dahlberg J. [eds.], Sorghum, 169-183. Humana Press, New York, New York, USA

Liu, T., Shen J.K., Li Z., Choy E., Hornicek F.J., Duan Z. (2016). Development and potential applications of CRISPR-Cas9 genome editing technology in sarcoma. Cancer Lett. 373:109118.

Ma H, Dang Y, Wu Y, et al. (2015). A CRISPRbased screen identifies genes essential for West-Nile-Virus-induced cell death. Cell Rep 12:673-83.

Ma, Y., Shen, B., Zhang, X., et al. (2014). Heritable multiplex genetic engineering in rats using CRISPR/Cas9. PLoS One 9:e89413

Macovei A., Sevilla N. R., Cantos C., Jonson G. B., Slamet-Loedin I., Èermák T., et al. (2018). Novel alleles of rice eIF4G generated by CRISPR/Cas9-targeted mutagenesis confer resistance to Rice tungro spherical virus. Plant Biotechnol. J. 16 1918-1927.

Mahas A., Neal Stewart C., Mahfouz M.M. (2018). Harnessing CRISPR/Cas systems for programmable transcriptional and posttranscriptional regulation. Biotechnol. Adv. 36:295-310.

Makarova, K.S., Grishin, N.V., Shabalina, S.A., Wolf, Y.I., and Koonin, E.V. (2006). A putative RNA-interference-based immune system in prokaryotes: computational analysis of the predicted enzymatic machinery, functional analogies with eukaryotic RNAi, and hypothetical mechanisms of action. Biol. Direct. 17

Mali P, Aach J, Stranges PB, et al. (2013). CAS9 transcriptional activators for target specificity screening and paired nickases for cooperative genome engineering. Nat Biotechnol 31:8338.

Mali, P., Yang, L., Esvelt, K.M., Aach, J., Guell, M., DiCarlo, J.E., Norville, J.E., Church, G.M. (2013). RNA-guided human genome engineering via Cas9. Science 339:823-826.

Malnoy M., Viola R., Jung M.-H., Koo O.-J., Kim S., Kim J.-S., Velasco R., Nagamangala Kanchiswamy C. (2016). DNA-free genetically edited grapevine and apple protoplast using CRISPR/Cas9 ribonucleoproteins. Front. Plant Sci.7:1904.

Maruyama, T., Dougan, S.K., Truttmann, M.C., et al. (2015). Increasing the efficiency of precise genome editing with CRISPR-Cas9 by inhibition of nonhomologous end joining. Nat Biotechnol 33:538-42.

Miao J., Guo D., Zhang J., Huang Q., Qin G., Zhang X., et al. (2013). Targeted mutagenesis in rice using CRISPR-Cas system. Cell Res. 23 12331236.

Modrzejewski, D., Hartung F., Sprink T., Krause D., Kohl C., and Wilhelm R. (2019). What is the available evidence for the range of applications of genome editing as a new tool for plant trait modification and the potential occurrence of associated off target effects: A systematic map. Environmental Evidence 8: 27.

Moehle, E.A., Rock, J.M., Lee, Y.L., Jouvenot, Y., DeKelver, R.C., Gregory, P.D., Urnov, F.D., Holmes, MC. (2007). Targeted gene addition into a specified location in the human genome using designed zinc finger nucleases. Proc Natl Acad Sci 104: 3055-3060.

Mojica MJ, Juez G, Rodríguez-Valera F. 1993. Transcription at different salinities of Haloferax mediterranei sequences adjacent to partially modified PstI sites. Mol Microbiol 9:613-621.

Moore, J.K., Haber J.E. (1996). Cell cycle and genetic requirements of two pathways of nonhomologous end-joining repair of doublestrand breaks in Saccharomyces cerevisiae. Mol. Cell. Biol. 16:2164-2173.

Moscou, M.J., Bogdanove, A.J. (2009). A simple cipher governs DNA recognition by TAL effectors. Science 326: 1501.

Mout R, Ray M, Yesilbag Tonga G, et al. (2017). Direct cytosolic delivery of CRISPR/Cas9ribonucleoprotein for efficient gene editing. ACS Nano 11:2452-8.

Mussolino, C., Alzubi, J., Fine, E.J., Morbitzer, R., Cradick, T.J., Lahaye, T., Bao, G., Cathomen, T. (2014). TALENs facilitate targeted genome editing in human cells with high specificity and low cytotoxicity. Nucleic Acids Res 42: 6762-6773.

Nekrasov V, Staskawicz B, Weigel D, Jones JD, Kamoun S. (2013). Targeted mutagenesis in the model plant Nicotiana benthamiana using Cas9 RNA-guided endonuclease. Nat Biotechnol 31: 691-693.

[Citation: Tahir, T., Ali, Q., Rashid, M.S., Malik, A. (2020). The journey of CRISPR-cas9 from bacterial defense mechanism to a gene editing tool in both animals and plants. Biol. Clin. Sci. Res. J., 2020: 17. doi: https://doi.org/10.54112/bcsrj.v2020i1.17] 
Nishitani C., Hirai N., Komori S., Wada M., Okada K., Osakabe K., et al. (2016). Efficient genome editing in apple using a CRISPR/Cas9 system. Sci. Rep. 6:31481.

Osakabe Y., Osakabe K. Progress in Molecular Biology and Translational Science. Volume 149. Elsevier; Amsterdam, The Netherlands: 2017. Genome Editing to Improve Abiotic Stress Responses in Plants; pp. 99-109.

Papapetrou EP, Schambach A. (2016). Gene insertion into genomic safe harbors for human gene therapy. Mol Ther 24:678-84.

Paques, F., Duchateau, P. (2007). Meganucleases and DNA double-strand break-induced recombination: perspectives for gene therapy. Curr Gene Ther 7: 49-66.

Pardo B., Gómez-González B., Aguilera A. (2009). DNA double-strand break repair: How to fix a broken relationship. Cell. Mol. Life Sci. 66:1039-1056.

Pattanayak, V., Ramirez, C.L., Joung, J.K., Liu, D.R. (2011). Revealing off-target cleavage specificities of zinc-finger nucleases by in vitro selection. Nat Methods 8: 765-770.

Pessina S., Lenzi L., Perazzolli M., Campa M., Dalla Costa L., Urso S., Valè G., Salamini F., Velasco R., Malnoy M. (2016). Knockdown of MLO genes reduces susceptibility to powdery mildew in grapevine. Hortic. Res. 3:16016.

Platt R.J., Chen S., Zhou Y., Yim M.J., Swiech L., Kempton H.R., Dahlman J.E., Parnas O., Eisenhaure T.M., Jovanovic M., et al. (2014).CRISPR-Cas9 Knockin Mice for Genome Editing and Cancer Modeling. Cell. 159:440-455.

Porteus MH, Carroll D. (2005). Gene targeting using zinc finger nucleases. Nat Biotechnol 23: $967-$ 973.

Pyne M. E., Bruder M., Moo-Young M., Chung D. A., Chou C. P. (2014). Technical guide for genetic advancement of underdeveloped and intractable Clostridium. Biotechnol. Adv. 32, 623-641.

Pyott D. E., Sheehan E., Molnar A. (2016). Engineering of CRISPR/Cas9-mediated potyvirus resistance in transgene-free Arabidopsis plants. Mol. Plant Pathol. 17 1276-1288.

Qi W., Zhu T., Tian Z., Li C., Zhang W., Song R. (2016). High-efficiency CRISPR/Cas9 multiplex gene editing using the glycine tRNA-processing system-based strategy in maize. BMC Biotechnol.16:58.
Ramakrishna, S., Kwaku, Dad, A.B., Beloor, J., et al. (2014). Gene disruption by cell-penetrating peptide-mediated delivery of Cas 9 protein and guide RNA. Genome Res 24:1020-7.

Ran, F.A., Hsu, P.D., Lin, C.Y., Gootenberg, J.S., Konermann, S., Trevino, A.E., Scott, D.A., Inoue, A., Matoba, S., Zhang, Y., et al. (2013). Double nicking by RNA-guided CRISPR Cas9 for enhanced genome editing specificity. Cell 154: 1380-1389.

Raschmanova H., Weninger A., Glieder A., Kovar K., Vogl T. (2018). Implementing CRISPRCas technologies in conventional and nonconventional yeasts: current state and future prospects. Biotechnol. Adv. 36, 641-665.

Ricroch A., Clairand P., Harwood W. (2017). Use of CRISPR systems in plant genome editing: toward new opportunities in agriculture. Emerg. Top. Life Sci. 1: 169-182.

Rodríguez-Leal D., Lemmon Z. H., Man J., Bartlett M. E., Lippman Z. B. (2017). Engineering quantitative trait variation for crop improvement by genome editing. Cell 171, 470-480.e8.

Rosinski-Chupin, I., Sauvage E., Fouet A., Poyart C., Glaser P. (2019). Conserved and specific features of Streptococcus pyogenes and Streptococcus agalactiae transcriptional landscapes. BMC Genomics 20, 236.

Samulski RJ, Muzyczka N. (2014). AAV-mediated gene therapy for research and therapeutic purposes. Annu Rev Virol 1:427-51.

Sánchez-León S., Gil-Humanes J., Ozuna C.V., Giménez M.J., Sousa C., Voytas D.F., Barro F. (2018). Low-gluten, nontransgenic wheat engineered with CRISPR/Cas9. Plant Biotechnol. J. 16:902-910.

Sander, J. D., and Joung J. K.. 2014. CRISPR-Cas systems for editing, regulating and targeting genomes. Nature Biotechnology 32: 347-355.

Savary S., Ficke A., Aubertot J. N., Hollier C. (2012). Crop losses due to diseases and their implications for global food production losses and food security. Food Secur. 4 519-537.

Savary S., Willocquet L., Pethybridge S.J., Esker P., McRoberts N., Nelson A. (2019). The global burden of pathogens and pests on major food crops. Nat. Ecol. Evol. 3:430-439.

Schwank G., Koo B.K., Sasselli V., Dekkers J.F., Heo I., Demircan T., Sasaki N., Boymans S., Cuppen E., Van Der Ent C.K., et al. (2013). Functional repair of CFTR by CRISPR/Cas9

[Citation: Tahir, T., Ali, Q., Rashid, M.S., Malik, A. (2020). The journey of CRISPR-cas9 from bacterial defense mechanism to a gene editing tool in both animals and plants. Biol. Clin. Sci. Res. J., 2020: 17. doi: https://doi.org/10.54112/bcsrj.v2020i1.17] 
in intestinal stem cell organoids of cystic fibrosis patients. Cell Stem Cell. 13:653-658.

Shah T., Andleeb T., Lateef S., Noor M. A. (2018). Genome editing in plants: advancing crop transformation and overview of tools. Plant Physiol. Biochem. 131, 12-21.

Shan, Q. , Wang Y., Li J., Zhang Y., Chen K., Liang Z., Zhang K., et al. 2013. Targeted genome modification of crop plants using a CRISPRCas9 system. Nature Biotechnology 31: 686688.

Shan, S. , Mavrodiev E. V., Li R., Zhang Z., Hauser B. A., Soltis P. S., Soltis D. E., and Yang B. (2018). Application of CRISPR/Cas9 to Tragopogon (Asteraceae), an evolutionary model for the study of polyploidy. Molecular Ecology Resources 18: 1427-1443.

Shen B., Zhang W., Zhang J., Zhou J., Wang J., Chen L., Wang L., Hodgkins A., Iyer V., Huang X., and Skarnes W. C. (2014) Efficient genome modification by CRISPR-Cas9 nickase with minimal off-target effects. Nat. Meth. 11, 399402

Shen, B., Zhang, J., Wu, H., et al. (2013). Generation of gene-modified mice via Cas9/RNAmediated gene targeting. Cell Res 23:720-3.

Shi J., Gao H., Wang H., Lafitte H. R., Archibald R. L., Yang M., et al. (2017). ARGOS 8 variants generated by CRISPR-Cas9 improve maize grain yield under field drought stress conditions. Plant Biotechnol. J. 15, 207-216.

Shukla, V.K., Doyon, Y., Miller, J.C., DeKelver, R.C., Moehle, E.A., et al. (2009) Precise genome modification in the crop species Zea mays using zinc-finger nucleases. Nature 459: 437-441.

Slaymaker, I.M., Gao, L., Zetsche, B., et al. (2016). Rationally engineered Cas9 nucleases with improved specificity. Science 351:84-8.

Smith. J., Grizot, S., Arnould, S., Duclert, A., Epinat, J.C., Chames, P., Prieto, J., Redondo, P., Blanco, F.J., Bravo, J., Montoya, G., Pâques, F., Duchateau, P. (2006). A combinatorial approach to create artificial homing endonucleases cleaving chosen sequences. Nucleic Acids Res. 34(22):e149.

Sternberg S. H., Redding S., Jinek M., Greene E. C., Doudna J. A. (2014). DNA interrogation by the CRISPR RNA-guided endonuclease Cas9. Nature 507: 62-67. 10.1038/nature13011.

Stoddard, B.L. (2005). Homing endonuclease structure and function. $Q$ Rev Biophys 38: 4995.
Stoddard, Barry L. (2006). "Homing endonuclease structure and function". Quarterly Reviews of Biophysics. 38 (1): 49-95.

Suda T, Gao X, Stolz DB, Liu D. (2007). Structural impact of hydrodynamic injection on mouse liver. Gene Ther 14:129-37.

Sun W, Ji W, Hall JM, et al. (2015). Self-assembled DNA nanoclews for the efficient delivery of CRISPR-Cas9 for genome editing. Angew Chem Int Ed Engl 54:12029-33.

Sun W, Jiang T, Lu Y, et al. (2014). Cocoon-like self-degradable DNA nanoclew for anticancer drug delivery. J Am Chem Soc 136:14722-5.

Sun Y., Jiao G., Liu Z., Zhang X., Li J., Guo X., Du W., Du J., Francis F., Zhao Y., et al. (2018). Generation of High-Amylose Rice through CRISPR/Cas9-Mediated Targeted Mutagenesis of Starch Branching Enzymes. Front. Plant Sci. 8:298.

Swiech L., Heidenreich M., Banerjee A., Habib N., Li Y., Trombetta J., Sur M., Zhang F. (2015). In vivo interrogation of gene function in the mammalian brain using CRISPR-Cas9. Nat. Biotechnol. 33:102-106.

Szostak J.W., Orr-Weaver T.L., Rothstein R.J., Stahl F.W. (1983). The double-strand-break repair model for recombination. Cell, 33:25-35.

Takeuchi, R., Choi, M., Stoddard, B.L. (2014). Redesign of extensive protein-DNA interfaces of meganucleases using iterative cycles of in vitro compartmentalization. Proc Natl Acad Sci U S A. 111(11):4061-6.

Thomas V., Hartner F. S., Anton G. (2013). New opportunities by synthetic biology for biopharmaceutical production in Pichia pastoris. Curr. Opin. Biotech. 24, 1094-1101. 10.1016/j.copbio.2013.02.024

Thomazella D.P.D.T., Brail Q., Dahlbeck D., Staskawicz B.J. (2016). CRISPR-Cas9 mediated mutagenesis of a DMR6 ortholog in tomato confers broad-spectrum disease resistance. bioRxiv. 2016.

Thyme, S.B., Boissel, S.J., Arshiya, Quadri, S., Nolan, T., Baker, D.A., Park, R.U., Kusak, L., Ashworth, J., Baker, D. (2014). Reprogramming homing endonuclease specificity through computational design and directed evolution. Nucleic Acids Res. 42(4):2564-76

Torres, R., Martin, M.C., Garcia, A., Cigudosa, J.C., Ramirez, J.C., Rodriguez-Perales, S. (2014). Engineering human tumour-associated chromosomal translocations with the RNA-

[Citation: Tahir, T., Ali, Q., Rashid, M.S., Malik, A. (2020). The journey of CRISPR-cas9 from bacterial defense mechanism to a gene editing tool in both animals and plants. Biol. Clin. Sci. Res. J., 2020: 17. doi: https://doi.org/10.54112/bcsrj.v2020i1.17] 
guided CRISPR-Cas9 system. Nat Commun 5: 3964

Trenberth K. E., Dai A., Van Der Schrier G., Jones P. D., Barichivich J., Briffa K. R., et al. (2014). Global warming and changes in drought. Nat. Clim. Change 4, 17.

Urnov, F.D., Rebar, E.J., Holmes, M.C., Zhang, H.S., Gregory, P.D. (2010). Genome editing with engineered zinc finger nucleases. Nat Rev Genet 11: 636-646.

Valsalakumari J., Baby J., Bijin E., Constantine I., Manjila S., Pramod K. (2013). Novel gene delivery systems. Int. J. Pharm. Investig. 3:1.

van Regenmortel M.H., Mahy B.W. Desk Encyclopedia of Plant and Fungal Virology. Elsevier; San Diego, CA, USA: 2009.

Vartak, S.V., Raghavan, S.C. (2015). Inhibition of nonhomologous end joining to increase the specificity of CRISPR/Cas9 genome editing. FEBS J 282:4289-94.

Voets O, Tielen F, Elstak E, et al. (2017). Highly efficient gene inactivation by adenoviral CRISPR/Cas9 in human primary cells. PLoS One 12: 0182974.

Waltz E. (2016). Gene-edited CRISPR mushroom escapes US regulation. Nature 532: 293.

Wang D., Samsulrizal N.H., Yan C., Allcock N.S., Craigon J., Blanco-Ulate B., Ortega-Salazar I., Marcus S.E., Bagheri H.M., Fons L.P. (2019). Characterization of CRISPR Mutants Targeting Genes Modulating Pectin Degradation in Ripening Tomato. Plant Physiol. 179:544-557.

Wang F., Wang C., Liu P., Lei C., Hao W., Gao Y., Liu Y.-G., Zhao K. (2016). Enhanced rice blast resistance by CRISPR/Cas9-targeted mutagenesis of the ERF transcription factor gene OsERF922. PLoS ONE. 11:e0154027.

Wang L., Chen L., Li R., Zhao R., Yang M., Sheng J., et al. (2017). Reduced drought tolerance by CRISPR/Cas9-mediated SIMAPK3 mutagenesis in tomato plants. J. Agric. Food Chem. 65, 8674-8682.

Wang M, Zuris JA, Meng F, et al. (2016). Efficient delivery of genome-editing proteins using bioreducible lipid nanoparticles. Proc Natl Acad Sci USA 113:2868-73.

Wang S., Dong S., Wang P., Tao Y., Wang Y. (2017). Genome Editing in Clostridium saccharoperbutylacetonicum N1-4 with the CRISPR-Cas9 system. Appl. Environ. Microbiol. 83:e00233-17.

Wang W., Pan Q., He F., Akhunova A., Chao S., Trick H., et al. (2018). Transgenerational
CRISPR-Cas9 activity facilitates multiplex gene editing in allopolyploid wheat. CRISPR J. 1, 65-74.

Wang X., Wang Y., Wu X., Wang J., Wang Y., Qiu Z., Chang T., Huang H., Lin R.J., Yee J.K. (2015). Unbiased detection of off-target cleavage by CRISPR-Cas9 and TALENs using integrase-defective lentiviral vectors. Nat. Biotechnol. 33:175-178.

Wang Y., Cheng X., Shan Q., Zhang Y., Liu J., Gao C., Qiu J. (2014). Simultaneous editing of three homoeoalleles in hexaploid bread wheat confers heritable resistance to powdery mildew. Nat. Biotechnol. 32:947.

Waters, C.A., Strande N.T., Pryor J.M., Strom C.N., Mieczkowski P., Burkhalter M.D., Oh S., Qaqish B.F., Moore D.T., Hendrickson E.A., et al. (2014). The fidelity of the ligation step determines how ends are resolved during nonhomologous end joining. Nat. Commun. 5:4286.

Weeks, D.P., Spalding M. H., Yang B. (2016). Use of designer nucleases for targeted gene and genome editing in plants. Plant Biotechnol. J. 14: $483-495$.

Weirauch MT, Hughes TR. (2010). Conserved expression without conserved regulatory sequence: the more things change, the more they stay the same. Trends in Genetics. 26(2):66-74.

Wenzhi, J., Huanbin, Z., Honghao, B., Michael, F. and Bing, Y., Weeks Donald P. (2013): Demonstration of CRISPR/Cas9/sgRNAmediated targeted gene modification in Arabidopsis, tobacco, sorghum and rice. Nucleic Acids Research, 41, pp.e188-e188.

White MK, Khalili K. (2016). CRISPR/Cas9 and cancer targets: future possibilities and present challenges. Oncotarget. 7:12305-12317.

Wolt J. D., Wang K., Yang B. (2016). The regulatory status of genome-edited crops. Plant Biotechnol. J. 14 510-518.

Woo, J. W. , Kim J., Kwon S. I., Corvalán C., Cho S. W., Kim H., Kim S. G., et al. (2015). DNA-free genome editing in plants with preassembled CRISPR-Cas9 ribonucleoproteins. Nature Biotechnology 33: $1162-1164$.

Wu J.J., Du G.C., Chen J., Zhou J.W. (2015). Enhancing flavonoid production by systematically tuning the central metabolic pathways based on a CRISPR interference system in Escherichia coli. Sci. Rep. 5:13477.

[Citation: Tahir, T., Ali, Q., Rashid, M.S., Malik, A. (2020). The journey of CRISPR-cas9 from bacterial defense mechanism to a gene editing tool in both animals and plants. Biol. Clin. Sci. Res. J., 2020: 17. doi: https://doi.org/10.54112/bcsrj.v2020i1.17] 
Wu Z, Yang H, Colosi P. (2010). Effect of genome size on AAV vector packaging. Mol Ther 18:80-6

Xie, K. , and Yang Y.. 2013. RNAguided genome editing in plants using a CRISPR-Cas9 system. Molecular Plant 6: 1975

Xu R., Yang Y., Qin R., Li H., Qiu C., Li L., et al. . (2016). Rapid improvement of grain weight via highly efficient CRISPR/Cas9-mediated multiplex genome editing in rice. J. Genet. Genomics 43, 529-532.

Xu, T., Li, Y., Shi, Z., Hemme, C.L., Li, Y., Zhu, Y., Van, Nostrand, J.D., He, Z., Zhou, J. (2015). Efficient genome editing in Clostridium cellulolyticum via CRISPR-Cas9 nickase. Appl Environ Microbiol 81:4423-4431.

Xue W., Chen S., Yin H., Tammela T., Papagiannakopoulos T., Joshi N.S., Cai W., Yang G., Bronson R., Crowley D.G., et al. (2014). CRISPR-mediated direct mutation of cancer genes in the mouse liver. Nature. 514:380-384.

Yin H, Song CQ, Dorkin JR, et al. (2016). Therapeutic genome editing by combined viral and non-viral delivery of CRISPR system components in vivo. Nat Biotechnol 34:32833.

Yin H., Xue W., Chen S., Bogorad R.L., Benedetti E., Grompe M., Koteliansky V., Sharp P.A., Jacks T., Anderson D.G. (2013). Genome editing with Cas9 in adult mice corrects a disease mutation and phenotype. Nat. Biotechnol. 32:551-553.

Yu, C., Liu, Y., Ma, T., et al. (2015). Small molecules enhance CRISPR genome editing in pluripotent stem cells. Cell Stem Cell 16:1427.

Zeisel, M.B., Lucifora J., Mason W.S., Sureau C., Beck J., Levrero M., Kann M., Knolle P.A., Benkirane M., Durantel D., et al. (2015). Towards an HBV cure: State-of-the-art and unresolved questions-report of the ANRS workshop on HBV cure. Gut. 64:1314-1326.

Zetsche B., Gootenberg J.S., Abudayyeh O.O., Slaymaker I.M., Makarova K.S., Essletzbichler P., Volz S.E., Joung J., van der Oost J., Regev A., et al. (2015). Cpf1 is a single RNA-guided endonuclease of a class 2 CRISPR-Cas system. Cell.163:759-771.

Zhang A., Liu Y., Wang F., Li T., Chen Z., Kong D., Bi J., Zhang F., Luo X., Wang J. (2019). Enhanced rice salinity tolerance via CRISPR/Cas9-targeted mutagenesis of the OsRR22 gene. Mol. Breed. 39:47.
Zhang C., Meng X., Wei X., Lu L. (2016). Highly efficient CRISPR mutagenesis by microhomology-mediated end joining in Aspergillus fumigatus. Fungal Genet. Biol. 86, 47-57.

Zhang F., Wen Y., Guo X. (2014). CRISPR for genome editing: progress, implications and challenges. Hum. Mol. Genet. 23 40-46.

Zhang J., Zhang H., Botella J.R., Zhu J. (2018). Generation of new glutinous rice by CRISPR/Cas9-targeted mutagenesis of the Waxy gene in elite rice varieties. J. Integr. Plant Biol. 60:369-375.

Zhang X., Lu G., Long W., Zou X., Li F., Nishio T. (2014). Recent progress in drought and salt tolerance studies in Brassica crops. Breed Sci. 64, 60-73.

Zhang Y, Ma X, Xie X, Liu Y-G. (2017). CRISPR/Cas9-based genome editing in plants. Prog Mol Biol Transl Sci 149:133-50.

Zhang Y., Massel K., Godwin I. D., Gao C. (2018b). Applications and potential of genome editing in crop improvement. Genome Biol. 19, 210.

Zhang Y., Yu L.C. (2008). Single-cell microinjection technology in cell biology. BioEssays. 30:606610.

Zhen S, Hua L, Liu YH, et al. (2015). Harnessing the clustered regularly interspaced short palindromic repeat (CRISPR)/CRISPRassociated Cas 9 system to disrupt the hepatitis B virus. Gene Ther 22:404-12.

Zhou Y, Zhu S, Cai C, et al. (2014). High-throughput screening of a CRISPR/Cas9 library for functional genomics in human cells. Nature 509:487-91.

Zhu M., Monroe J. G., Suhail Y., Villiers F., Mullen J., Pater D., et al. (2016). Molecular and systems approaches towards drought-tolerant canola crops. New Phytol. 210, 1169-1189.

\section{(c) (1) \&}

Open Access This article is licensed under a Creative Commons Attribution 4.0 International License, which permits use, sharing, adaptation, distribution and reproduction in any medium or format, as long as you give appropriate credit to the original author(s) and the source, provide a link to the Creative Commons licence, and indicate if changes were made. The images or other third party material in this article are included in the article's Creative Commons licence, unless indicated otherwise in a credit line to the material. If material is not included

[Citation: Tahir, T., Ali, Q., Rashid, M.S., Malik, A. (2020). The journey of CRISPR-cas9 from bacterial defense mechanism to a gene editing tool in both animals and plants. Biol. Clin. Sci. Res. J., 2020: 17. doi: https://doi.org/10.54112/bcsrj.v2020i1.17] 
in the article's Creative Commons licence and your intended use is not permitted by statutory regulation or exceeds the permitted use, you will need to obtain permission directly from the copyright holder. To view a copy of this licence, visit http://creativecommons.org/licen ses/by/4.0/.

(C) The Author(s) 2021

[Citation: Tahir, T., Ali, Q., Rashid, M.S., Malik, A. (2020). The journey of CRISPR-cas9 from bacterial defense mechanism to a gene editing tool in both animals and plants. Biol. Clin. Sci. Res. J., 2020: 17. doi: https://doi.org/10.54112/bcsri.v2020i1.17] 